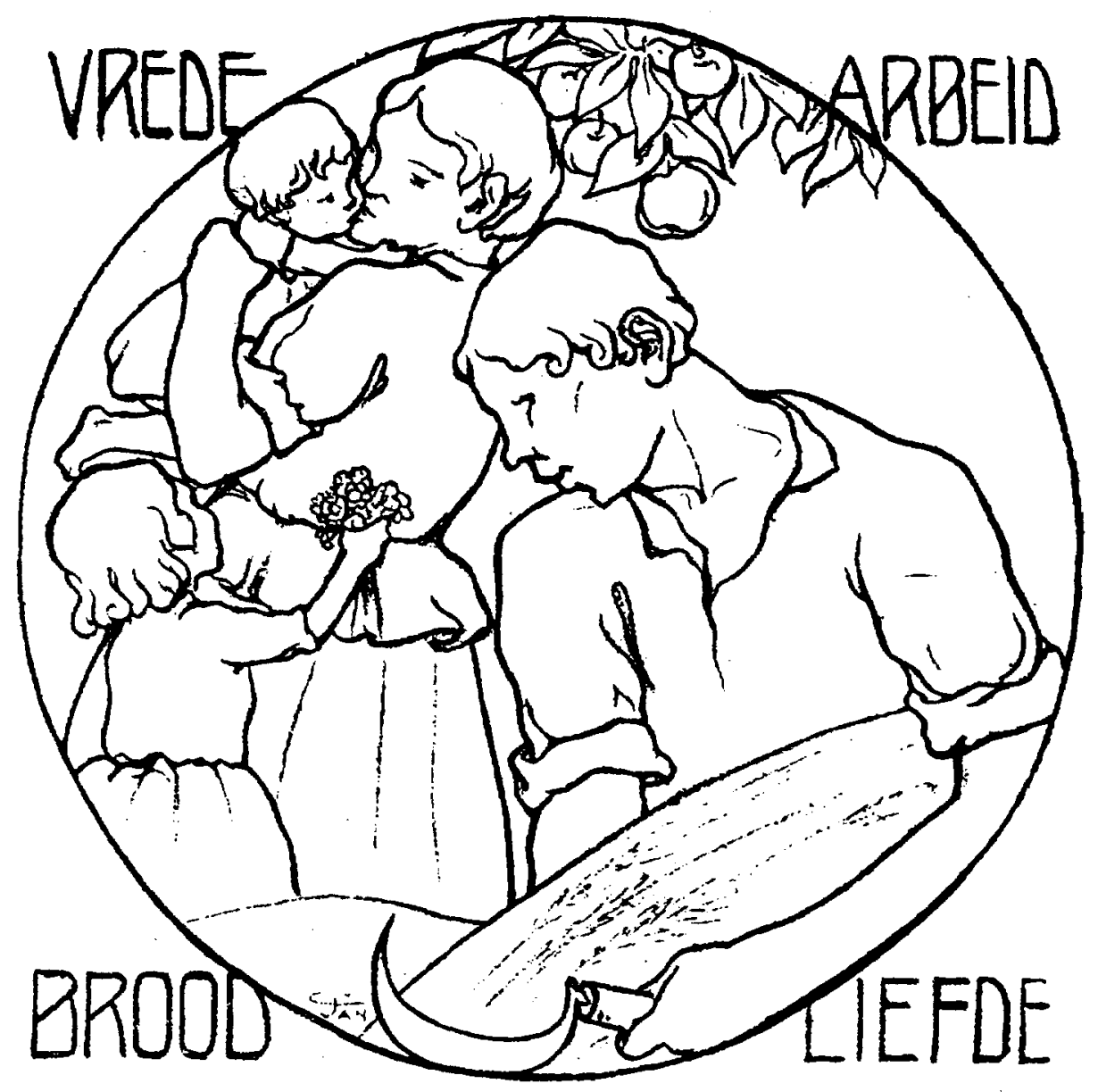

Het ideale socialistiscbe buisgezin? Prent verschenen in bet Eén-Meialbum van Vooruit, 1914 


\section{Koningin van het huisgezin of volwaardige arbeidskracht?}

De visies van de Belgische Werkliedenpartij op de fabrieksarbeid van vrouwen. 1885-1914.

Nele Bracke, licentiate geschiedenis $\mathrm{UG}^{*}$

\section{Inleiding.}

Van bij haar oprichting in 1885 streefde de Belgische Werkliedenpartij de "herziening [van het] wetboek dat politieke en civiele minderheid vaststelt van arbeiders, vrouwen, onwettige kinderen" na ${ }^{(1)}$. Het programma van Quaregnon uit 1894 bepaalde tevens dat de partij zou strijden voor het algemeen stemrecht zonder onderscheid van geslacht. Bovendien werd vastgelegd dat de BWP niet alleen de arbeiders vertegenwoordigde, maar alle verdrukten ongeacht hun nationaliteit, geloof, ras of geslacht ${ }^{(2)}$.

Niets in het partijprogramma stond de BWP in de weg om op te komen voor de belangen van de vrouwen. Integendeel, het programma bevatte een aanzet om de strijd voor de rechten van de vrouwen te koppelen aan die voor de rechten van de arbeiders. In dit artikel zal nagegaan worden op welke manier de partij de rechten van de vrouwen op de arbeidsmarkt invulde. Zowel in 1885 als in 1894 bepaalde het partijprogramma dat de BWP zou ijveren voor een verbod op vrouwenarbeid waar die strijdig was met de zeden of met de gezondheid. De BWP was op dit punt bijgevolg niet gewonnen voor een volledig gelijke behandeling van mannen en vrouwen. Het is echter de vraag hoe zwaar de intentie om de vrouwenarbeid in bepaalde gevallen te verbieden doorwoog op de partijstandpunten terzake in de periode voor de Eerste Wereldoorlog. Waren er socialisten die een stapje verder gingen en een totaal verbod op vrouwenarbeid eisten ? Kwamen anderen daarentegen op voor het recht op arbeid, ook voor vrouwen ? Hoe werden standpunten in deze of gene richting verantwoord? Naast een antwoord op deze vragen wordt tevens gepeild naar de continuïteit dan wel breuk in het socialistische denken over vrouwenarbeid vanaf Proudhon, Fourier en de Saint-Simonisten over Marx en Engels tot de Belgische socialisten uit de belle époque.

De bronnen die een - aanzet tot - antwoord kunnen geven op deze vragen zijn van de meest diverse aard. Voor wat de Belgische socialisten betreft, worden de verslagen van de partijcongressen geanalyseerd, evenals de officiële persorganen Vooruit aan Vlaamse en Le Peuple aan Waalse kant. Ook de socialistische vrouwenbeweging komt aan bod met haar congressen en pers 
- De Vrouw en De Stem der Vrouw voor Vlaanderen en Cahiers Féministes en La Femme Socialiste voor Wallonië. Onderzoek naar de standpunten van de socialistische vakbonden over de vrouwenarbeid buitenshuis is zo goed als onbestaande. De geïnteresseerde onderzoeker vindt er een onontgonnen werkterrein. Zelf hebben we ons wegens tijdgebrek en gezien de beperkte omvang van dit artikel niet op dit domein gewaagd.

Het antwoord op de vraag naar de breuk of continuiteit in het socialistische denken vanaf de utopische socialisten wordt gezocht in de congresverslagen van de Eerste Internationale, evenals in oorspronkelijke teksten van Fourier, de Saint-Simon, Proudhon, Marx en Engels en in de recente studies van Saskia Poldervaart ${ }^{(3)}$.

\section{Geen vrouwen meer in de fabrieken : het ideaal van de vrouw and de haard.}

\author{
Demanophet werk; \\ De moeder in 't huishouden; \\ Het kind bij moeder en in de school ${ }^{(4)}$.
}

Zowel in Vooruit als in Le Peuple en op de partijcongressen waren in de vooroorlogse periode regelmatig geluiden te horen die de vrouwen uit de fabrieken wilden weren. We mogen deze strekking binnen de BWP de "officiële partijlijn" noemen, vermits er resoluties in die zin goedgekeurd werden en onder de krantenartikels geregeld namen als "Louis Bertrand" en "Jean Volders" prijkten.

Er werd gepleit voor de "teruggave" van de vrouw aan het gezin en voor een taakverdeling waarbij de man buitenshuis ging werken om te zorgen voor een inkomen en de vrouw zich volledig aan het huishouden wijdde. Vaak klonk hierin door dat "dit de normale gang van zaken was" : de vrouwen hoorden thuis aan de haard, het was hun roeping om kinderen te krijgen en voor het huishouden en hun echtgenoot te zorgen. Dit was tevens een ideaal, vermits veel vrouwen het zich financieel niet konden veroorloven weg te blijven uit de fabrieken. Op het congres van 1896 vatte Smolders het als volgt samen :

[...] lidéal serait que la femme restât dans le rôle na- turelquiluiestassignéetqu'ellesebornâtà donneràla communauté des enfants sains et robustes et à les élever dans les meilleures conditions physiques et morales; qu'elle pûtn'être que compagne, mère et éducatrice; que sa vie appartint par conséquent essentiellement au foyer ${ }^{(5)}$.

Menig socialist meende dat de belangrijkste taak van de vrouwen het moederschap was ${ }^{(6)}$. Deze "missie" gaf de vrouwen een grote verantwoordelijkheid. Ze moesten immers zorgen voor een sterk en gezond nageslacht en voor de volgende generatie socialisten. Deze opdracht werd onverenigbaar geacht met een dagtaak in de industrie. Daarnaast hadden de vrouwen ook de taak het huishouden te leiden. De industriëlen hadden de vrouwen echter "weggerukt" uit het gezin, met alle gevolgen van dien. De industrie had de vrouwen ontstolen aan de werkkring die hen paste en hen tot arbeidsters en slaven van het kapitalisme gemaakt. Het gezin van buitenshuis werkende moeders werd verwaarloosd, erger nog, het was geen echt gezin meer. De fabrieksarbeidsters wisten niet meer hoe ze het huishouden moesten doen en hoe ze hun kinderen moesten verzorgen en opvoeden. Het verzaken van de arbeidsters aan hun "natuurlijke roeping" had een hoge kindersterfte tot gevolg ${ }^{(7)}$. De kinderen $z$ wierven langs de straten en de vrouwen waren niet langer de vriendin en levensgezellin van hun echtgenoot. De mannen brachten hun vrije tijd dan ook liever op café dan thuis door ${ }^{(8)}$.

De tegenstanders van de vrouwenarbeid buitenshuis vreesden vooral de gevolgen voor de gezondheid van de kinderen. Hun bekommernis om de gezondheid van de arbeidsters zelf was minder groot. Naast de schade die de arbeid van de vrouwen in mijnen en fabrieken toebrache aan het huishouden en de kinderen, had hij nog een 
ander nefast gevolg : de vrouwen werkten aan lagere lonen dan de mannen, waardoor ze de concurrentes van de arbeiders werden en de druk op de mannenlonen toenam.

Vooral dit laatste lag menig socialist zwaar op de maag. Het idee dat de vrouwen loonbederfsters waren die de lonen naar beneden trokken, dook geregeld op ${ }^{(9)}$. Daarenboven meende men dat de vrouwen de mannen uit de markt concurreerden. De dreiging dat de mannen massaal hun baan verloren aan de vrouwen daagde als een doembeeld op. In de Waalse pers werd benadrukt dat de lage vrouwenlonen eveneens totgevolg hadden dat de vrouwen een aanvullend loon moesten zoeken in de prostitutie ${ }^{(10)}$.

De fabrieksarbeid van vrouwen werd bijgevolg door een meerderheid van de socialisten negatief gewaardeerd. Het was danookde wensdroom van menig socialist dat de vrouwen geen fabrieksarbeid meer zouden verrichten. In de eerste plaats omdat de concurrentie die de mannen op de arbeidsmarkt van de vrouwen ondervonden zou verdwijnen. Bovendien zouden de vrouwen terug tijd hebben om voor het huishouden en de kinderen te zorgen en om van het huis een plaats te maken waar de man graag vertoefde. Op die manier zouden de mannen weggehouden worden van de cafés en van de drank.

De in hoofdzaak mannelijke socialisten die ijverden voor het ideaal van de vrouw aan de haard meenden evenwel dat ze deze strijd niet alleen moesten voeren, maar dat de vrouwen hen daar actiefbij moesten helpen ${ }^{(11)}$. De vrouwen werden dan ook aangemaand deel te nemen aan socialistische manifestaties, zoals de één-meibetogingen en te helpen bij de verspreiding van de socialistische ideeën. Daarnaast moesten de arbeidsters zich organiseren in vakbonden, zodat ze zelf konden ijveren voor de verbetering van hun economische situatie.

Ze meenden daarenboven dat het vrouw-aan-dehaard-ideaal nooit volledig gerealiseerd zou worden in een kapitalistische maatschappij, maar pas tot stand zou komen in een socialistische samenleving ${ }^{(12)}$. Er werd dan ook gewaarschuwd tegen de katholieke kerk die liet uitschijnen dat ze de vrouw bevrijd en tot de "koningin van het huishouden" verheven had. Het tegendeel was waar : de katholieken hadden de slavernij waarin de vrouwen zich bevonden bekrachtigd, getuige daarvan het wetboek. Alleen het socialisme zou de vrouwen echt bevrijden. Het was daarom de taak van elke sociaal-democraat zijn vrouw en dochters zo ver mogelijk van de betaalde arbeid te houden en zo mee te werken aan het verdwijnen van de loonarbeid en aan de verwezenlijking van de socialistische samenleving.

Zolang de kapitalistische maatschappij geen plaats had geruimd voor de socialistische, bleefde vrouwenarbeid evenwel tot de dagelijkse realiteit behoren. Er dienden dan ook een aantal praktische maatregelen genomen te worden om er onmiddellijk - nog voor de ondergang van het kapitalisme - paal en perk aan te stellen. In overeenstemming met het partijprogramma moesten de socialisten ijveren voor een degelijke arbeidswetgeving ${ }^{(13)}$. Het ging hierniet alleen om een nationale wetgeving. Om de internationale concurrentiepositie van België niet te ondermijnen, werd gepleit voor het tot stand komen van een internationale regeling van de vrouwenarbeid. De socialistische partij stond dan wel positief tegenover het principe van de arbeidswetgeving in het algemeen, wat de Belgische situatie in het bijzonder betrof, waren kritische geluiden te horen.

Ook al noemde Edward Anseele het wetsontwerp uit 1887 dat tot doel had de vrouwen- en kinderarbeid wettelijk te regelen het resultaat van de schrik die de socialistische massa de katholieken aangejaagd had, toch werd het in socialistische kringen vrij sceptisch onthaald ${ }^{(14)}$. Vooral voor de Vlamingen ging het niet vergenoeg, vermitsalleen de ondergrondse arbeid in mijnen en steengroeven verboden werd en dit pas vanaf $1892 . \mathrm{Ze}$ benadrukten dat voor de arbeidsters die bovengronds werkten niet veel zou veranderen, ook al 


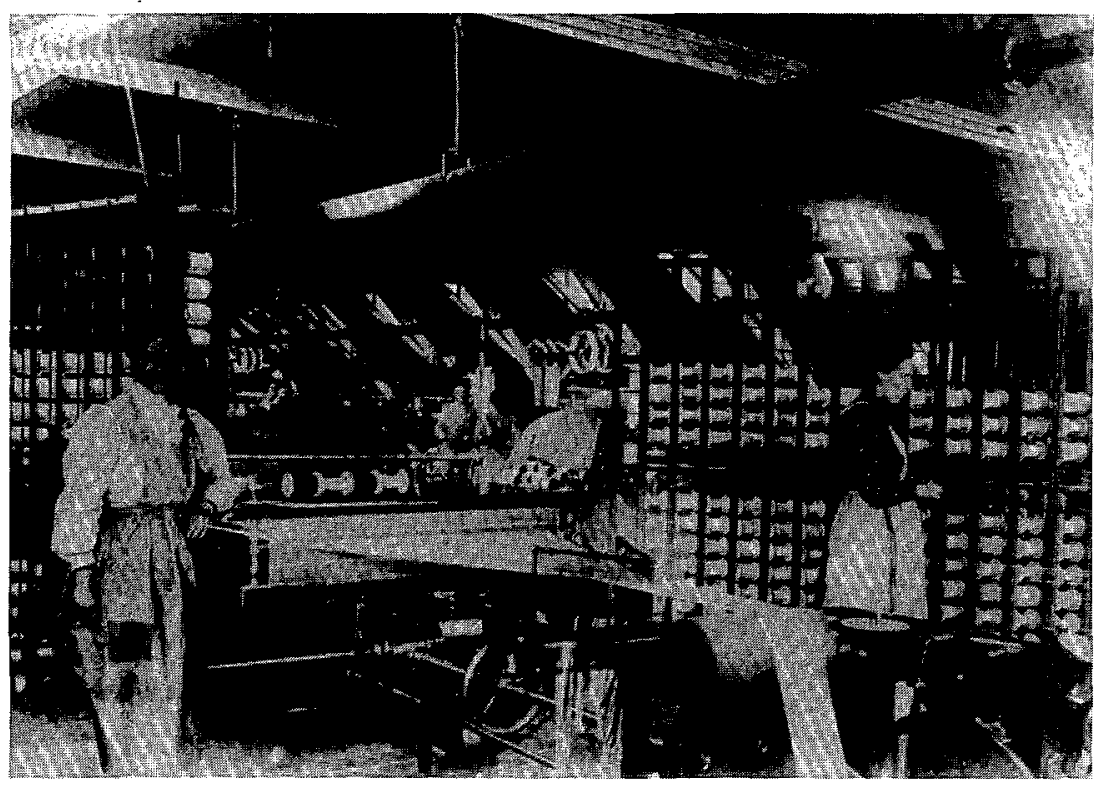

Vrouwenarbeid en lage lonen: bedreiging voor de mannen?

Textielarbeidsters vóór de Eerste Wereldoorlog

waren hier eveneens misbruiken. Er werd tevens gevreesd dat de wet niet nageleefd zou worden, omdat er weinig garanties in opgenomen waren om overtredingen te voorkomen. De arbeiders hadden daarom de taak eventuele misbruiken aan te klagen.

$\mathrm{Na}$ de volledige inwerkingtreding van de wet op de vrouwen-en kinderarbeid in 1892 bleef in socialistische kringen de overtuiging leven dat de Belgische wetgeving niet ver genoeg ging en achterop hinkte op die in het buitenland ${ }^{(15)}$. Er werden dan ook voorstellen gedaan om de wetgeving verder uit te breiden : nachtarbeid, evenals arbeid in sectoren die schadelijk waren voor de gezondheid van de vrouwen en hun nageslacht moest verboden worden, vrouwen moesten een aantal weken zwangerschapsverlof krijgen.

Aansluirend bij de eis de vrouwenarbeid te beperken door hem wettelijk te reglementeren gingen aan Waalse kant stemmen op voor een arbeidssegregatie op basis van het geslacht ${ }^{(16)}$. Zo zouden vrouwen bepaalde beroepen waarvoor de mannen beter geschikt waren aan hen moeten overlaten en bij voorkeur geen werk zoeken in concurrentie met de mannen. De opsplitsing van de industrie in "mannelijke" en "vrouwelijke" sectoren zou tot gevolghebben dat niet alle beroepen overspoeld werden door goedkopere arbeidsters, zodat het voor de mannen mogelijk bleef een leefbaar loon te verdienen.

De BWP moest de vrouwen daarenboven helpen zich opnieuw bewust te worden van hun "roeping", het moederschap. Het was daarom nodigde vrouwen op te voeden om hun taak als moeder en huisvrouw naar behoren te vervullen ${ }^{(17)}$. Door het inrichten van kook- en naailessen en door het geven van voordrachten over de opvoeding en de verzorging van de kinderen hoopte men de nefaste gevolgen van de vrouwenarbeid buitenshuis voor het gezin en de kinderen grotendeels te doen verdwijnen. Ook de kranten hielpen actief mee om van de fabrieksarbeidsters terug goede moeders en huishoudsters te maken door recepten en tips voor de moeders te publiceren ${ }^{(18)}$.

Naast de arbeidswetgeving die paal en perk moest stellen aan de vrouwenarbeid en de "training" van de vrouwen als huismoeders, diende gesleuteld te worden aan de lonen in de industrie. In Vlaanderen werd vooral gedacht aan het verhogen van de mannenlonen om de vrouwenarbeid over- 
bodig te maken ${ }^{(19)}$. Eens de mannen genoeg verdienden om het gezin te onderhouden, konden de vrouwen thuis blijven en zich volledig wijden aan het huishouden en de opvoeding van de kinderen. In Wallonië daarentegen was het meest gesuggereerde middel om de concurrentie tussen de mannen en de vrouwen op de arbeidsmarkt te bestrijden het betalen van een gelijk loon voor gelijk werk ${ }^{(20)}$. Op die manier zouden de vrouwen niet verdwijnen uit de fabrieken, iets wat wenselijk was gezien de vele vrouwen die moesten leven van hun eigen loon. Wel zouden de werkgevers er geen voordeel meer bij hebben om vrouwen tewerk te stellen enkel en alleen omdat ze hen minder moesten betalen. Bovendien zouden de arbeidsters een leefbaar loon verdienen, waardoor een einde kwam aan de noodzaak zich te prostitueren om te overleven.

De BWP nam een vrij radicaal standpunt in tegenover de fabrieksarbeid van vrouwen : de arbeidsters moesten zo vlug mogelijk uit de industrie verdwijnen en terugkeren naar de haard. Het verbod op vrouwenarbeid die strijdig was met gezondheid of goede zeden uit het partijprogramma was niet voldoende. Alle vrouwen moesten verdwijnen uit alle sectoren en welom het gezin veilig te stellen en - dit vooral - om een einde te maken aan de concurrentie met de mannen. Men zag echter in dat dit niet onmiddellijk mogelijk was : de industriëlen maakten dankbaargebruik van de goedkope vrouwelijke arbeidskrachten en de vrouwen hadden hun inkomen nodig. Pas met de overwinning van het socialisme zou de vrouw definitief uit de fabrieken verdwijnen. Voor het moment zouden een aantal maatregelen om de vrouwenarbeid te beperken moeten volstaan.

Maar wat met het recht op arbeid, of gold dit niet voor de vrouwen? En wat met de vrouwen die een loon moesten verdienen om te overleven ? $\mathrm{Zij}$ hadden er weinig baat bij dat hun arbeid beperkt, beschermd en gereglementeerd werd, omdat dit hun positie op de arbeidsmarkt ondermijnde. $\mathrm{Zij}_{\mathrm{ij}}$ eisten het recht om te overleven door te werken.
3. Geïnspireerd door realisme en noodzaak: recht op arbeid ook voor vrouwen.

Zijn wij vrouwen dan geene menschen ? Bestaat voor ons het recht op 't leven niet en het daaruit voortspruitende recht op arbeid ${ }^{(21)}$ ?

Hoewel de meerderheid van de socialisten tegen de fabrieksarbeid van vrouwen was, weerklonken toch regelmatig geluiden die het recht op arbeid voor vrouwen opeisten. De voorstanders moeten vooral gezocht worden in de kringen van de Vlaamse - socialistische vrouwenbeweging, al waren er ook socialistische vrouwen die ijverden voor het ideaal van de vrouw aan de haard ${ }^{(22)}$. De voornaamste spreekbuizen van de verdedigers van de vrouwenarbeid waren de vrouwencongressen en de vrouwentijdschriften De Vrouw, De Stem der Vrouw en Cahiers Féministes. Daarnaast vinden we ook in Le Peuple en Vooruit en op de algemene congressen verdedigers van het recht op arbeid voor vrouwen terug.

De verdedigers van de vrouwenarbeid - van wie de bekendste Emilie Claeys, Isabelle Gatti de Gamond, Hubert Rienzi Van Kol en zijn vrouw Nellie waren - mogen zonder overdrijven de "realisten" onder de socialisten genoemd worden. $\mathrm{Zij}$ zagen maar al te goed in dat het een utopie was dat vrouwen hun baan in de fabrieken zouden opgeven. De vooruitgang van de mechanisatie had bovendien tot gevolg dathet aantal vrouwen in de industrie steeg, vermits de machines ook door vrouwen bediend konden worden. Het ideaal van koningin aan de haard zweemde naar "sentimentalisme" (23), terwijl de vrouwen in werkelijkheid hun bijdrage moesten leveren tot het gezinsinkomen. Hoe zouden de gezinnen overleven zonder de bijdrage van vrouw en dochters ? Gesteld dat de werkgevers aan de arbeiders een gezinsloon uitbetaalden, dan was het probleem van de alleenstaande vrouwen en de vrouwen met een werkonbekwame man niet opgelost. $\mathrm{Zij}$ zouden altijd loonarbeid moeten verrichten, ook in een socialistische samenleving. Van de "teruggave" 
van de vrouwen aan het gezin kon dan ook geen sprake zijn. Het was daarom realistischer te strijden voor de erkenning van het recht op arbeid voor vrouwen en voor leefbare vrouwenlonen ${ }^{(24)}$. De voorstanders van de vrouwenarbeid waren het met de tegenstanders eens wat de wantoestanden in de industrie betrof. Vrouwen verrichtten dikwijls zware en ongezonde arbeid in onmenselijke omstandigheden en dat tegen een laag loon. Vooral de specifieke vrouwenberoepen waren uitermate slecht betaald. Maar ook in gemengde sectoren verdienden de vrouwen in regel minder dan hun mannelijke collega's die hetzelfde werk verrichtten. Alleenstaande vrouwen waren bijna gedwongen zich te prostitueren, van hun loon alleen konden ze immers niet overleven. Daarenboven was de arbeidsduur vaak onmenselijk hoog, waardoor de - gehuwde - arbeidsters geen tijd meer hadden om voor het huishouden te zorgen. De gezinnen met een werkende moeder gaven uiteindelijk meer geld uit dan wanneer de vrouw geen loonarbeid verrichtte ${ }^{(25)}$.Ze moesten immers een aantal dingen - zoals kledij en brood die vrouwen, die zich uitsluitend met het huishouden bezighielden zelf konden maken, op de markt kopen.

Werd de gezondheid van de arbeidsters en hun nageslacht inderdaad bedreigd, botste de fabrieksarbeid van de vrouw met de belangen van het huishouden en betekenden de lage vrouwenlonen een bedreiging voor de mannen, dan was dit geen reden om de vrouwenarbeid in de fabrieken te verbieden. Het probleem kon niet opgelost worden door de vrouwen uit de industrie te weren, maar door de arbeidsomstandigheden aan te pakken.

Het beperken van de vrouwenarbeid terwijl de mannenarbeid ongemoeid bleef, ging niet alleen voorbij aan het feit dat veel mannenarbeid even ongezond was, het had ook tot gevolg dat de concurrentiepositie van de vrouwen verzwakt werd. Het aantal vrouwen in de industrie daalde niet, maar de vrouwen raakten gemarginaliseerd in een beperkt aantal sectoren ${ }^{(26)}$. Veel werkgevers stelden lievergeen arbeidsters te werk, omdat hun arbeid aan allerlei beperkingen onderworpen was, ook al moesten ze minder betaald worden. De vrouwen vonden bijgevolg nog nauwelijks beter betaald werk en waren gedwongen hun toevlucht te zoeken in minderwaardige banen. Hier nam de concurrentie in dergelijke mate toe dat de lonen verder daalden. Het verbieden van de vrouwenarbeid had evenmin zin, omdat nog meer vrouwen dan een inkomen zouden moeten zoeken in de prostitutie of in de huisnijverheid. Het verbod zou bovendien alleen aanleiding geven tot het vervangen van de vrouwen door machines en zou de mannen dus niet ten goede komen ${ }^{(27)}$.

De gezondheid van de arbeiders werd inderdaad bedreigd, maar dat gold zowel voor de vrouwenals voor de mannen ${ }^{(28)}$. Geen enkele arbeid was immers schadelijk voor vrouwen alleen. Het had volgens de verdedigers van de vrouwenarbeid dan ook weinig zin om enkel de vrouwenarbeid te reglementeren. Er was nood aan een degelijke arbeidswetgeving voor mannen én vrouwen. Tot het zover was, moest de vrouwenarbeid volledig vrij gelaten worden. Geen enkele man had het recht de vrouwenarbeid te beperken en te oordelen over welke arbeid schadelijk was voor vrouwen en welke niet, zonder dat deze laatsten om hun mening gevraagd werd ${ }^{(29)}$. De wet ter bescherming van de vrouwen-en kinderarbeid in de fabrieken van 1889 en de daarop volgende wetten werden dan ook sceptisch onthaald.

Van het standpunt "geen bescherming van de vrouwenarbeid zonder bescherming van de mannenarbeid" werd enkel afgeweken voor zwangere vrouwen $^{(30)}$. In het belang van het nageslacht moest men hen meer dan andere arbeiders beschermen. Het beperken van hun arbeid in duur en soort, evenals het verlenen van zwangerschapsverlof werd daarom wel aanvaard. Een moederschapsverzekering kon de vrouwen in staat stellen dit verlof ook daadwerkelijk op te nemen. Zonder financiële compensatie probeerden de meesten immers zo snel mogelijk opnieuw 
aan de slag te gaan om het loonverlies te beperken. Emilie Claeys en Rienzi merkten evenwel op dat de gezondheid van de kinderen niet alleen bepaald werd door die van de moeder, maar ook door die van de vader. Zowat als enigen wezen zij bijgevolg ook het idee om zwangere vrouwen apart te beschermen van de hand (31).

Het argument van de voorstanders van de wettelijke reglementering van de vrouwenarbeid dat dit de voorbode was van de bescherming van alle arbeiders sneed volgens de feministen geen hout ${ }^{(32)}$. Integendeel, de bescherming van de vrouwenarbeid was een "zoethoudertje" voor dat deel van het parlement dat alle arbeid wilde reglementeren. Het verblindde hen, waardoor het juist moeilijker werd om een algemene arbeidsbescherming af te dwingen. Ook vanuit deze optiek was het dus belangrijk te ijveren voor de gelijke en gelijktijdige bescherming van alle arbeiders.

Tenslotte merkten de socialistische feministen op dat de bescherming van de vrouwenarbeid die door vele socialisten geëist werd, helemaal niet bedoeld was om de gezondheid of de zedelijkheid van de arbeidsters te beschermen. Integendeel, de eis om de arbeid van de vrouwen te beperken of te verbieden werd ingegeven door de schrik die de arbeiders hadden voor de concurrentie van de vrouwen. Ze meenden immers dat de goedkopere vrouwelijke arbeidskrachten de mannenlonen deden dalen en dat ze een bedreiging vormden voor de werkgelegenheid van de mannen ${ }^{(33)}$. De socialistische feministen ontkenden niet dat de vrouwen minder verdienden dan de mannen, net zo min als ze bestreden dat de goedkope arbeidsters de arbeidsplaatsen van de mannen konden bedreigen. In veel gevallen was een vrouwenloon niet eens voldoende om er kinderopvang tijdens de werkuren van te betalen, laat staan om er van te kunnen leven. In tegenstelling tot de voorstanders van de wettelijke regeling van de vrouwenarbeid meenden ze dat de concurrentie niet bestreden mocht worden door de vrouwen terug te dringen in het gezin. Men mocht de vrouwen het recht op arbeid niet ontzeggen. De mannenlonen zouden immers niet stijgen eens de vrouwen uit de industrie verdreven waren. De plaats van de arbeidsters zou daarentegen ingenomen worden door mannen die tegen dezelfde lage lonen werkten of door machines. Als alternatief werd voorgesteld de vrouwen in de industrie volledig gelijk te behandelen met de mannen. De vrouwen hadden ook het recht om door hun arbeid zelfstandig te $z$ ijn ${ }^{(34)}$.

Ze suggereerden daarom dat het principe van "gelijk loon voorgelijk werk" gerealiseerd zou worden (35). Zo ontstond een eerlijke concurrentie, die niet gebaseerd was op het geslacht, maar op vakkennis. Het argument van de werkgevers dat de lagere vrouwenlonen gerechtvaardigd waren, omdat vrouwen "minder behoeften" hadden of omdat hun loon slechts een aanvulling op dat van de man was, ging niet op. Niet alle vrouwen konden immers terugvallen op het loon van een man. De arbeid van vrouwen was bovendien evenveel waard als die van mannen en diende dus op dezelfde manier beloond te worden.

De mannelijke arbeiders hadden er alle voordeel bij dat de vrouwen evenveel zouden verdienen als zij, omdat de arbeidsters dan niet langer "loonbederfsters" waren. Het was dan ook in hun eigen belang om van de vrouwen medestandsters te maken door hen toe te laten in de vakbonden in plaats van hen te vrezen en angstvallig te weren uit de arbeidersorganisaties. "Gelijk loon voor gelijk werk" kwam niet alleen de mannen ten goede, het garandeerde ook dat de vrouwen een leefbaar loon verdienden. Deze eis was dan ook deels feministisch geïnspireerd. De arbeidsters zouden immers financieel onafhankelijk worden van de mannen, wat een stap vooruit betekende in de emancipatie van de vrouwen.

Een andere belangrijkestap op weg naarbetere arbeidsvoorwaarden voor vrouwen en mannen moest erin bestaan hun arbeidsduur te beperken ${ }^{(36)}$. Dit zou hun arbeid minder afmattend maken. Bovendien zouden ze dan meer tijd kunnen doorbrengen in het gezin. Dit was voor beide geslachten belangrijk, maar voor de vrouwen had het als 


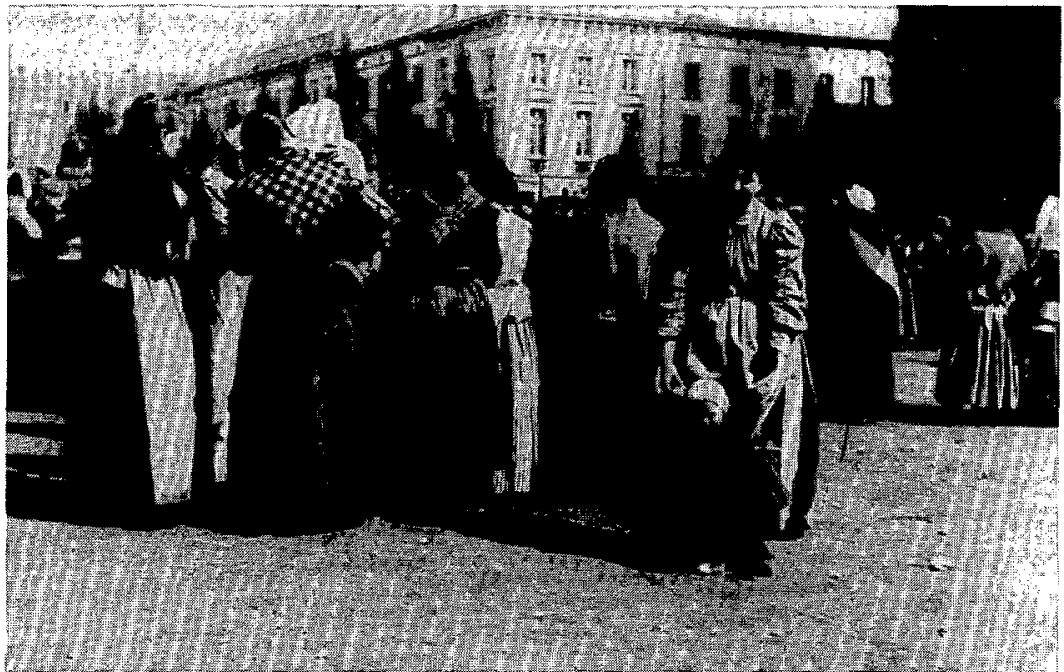

\author{
Vrouwen betogen \\ voor Algemeen \\ Stemrecbt, Gent, 1893 \\ (foto Vander Haeghen)
}

bijkomend voordeel dat ze meer tijd konden besteden aan het huishouden en de opvoeding van de kinderen. De verdedigers van de vrouwenarbeid waren het immers met de tegenstanders ervan eens dat de vrouwenarbeid nefaste gevolgen voor het huishouden en de kinderen had. Ze zagen in dat de arbeid van de vrouw niet altijd te verzoenen was met het huishouden. Dit conflict moest echter niet opgelost worden door de vrouwen uit de fabriek te weren, maar door enerzijds de arbeidsduur te verkorten en anderzijds de huishoudelijke taken te verlichten ${ }^{(37)}$. De vrouwen moesten bevrijd worden van een heleboel overbodige taken als koken, wassen en strijken. Daarenboven moest de kinderopvang degelijk uitgebouwd worden.

Hoewel de voorstellen van de socialistische feministen er niet op gericht waren de vrouwen van de arbeidsmarkt te verdrijven, meenden sommigen dat de vrouwen het recht hadden te kiezen voor het huishouden. Vrouwen die zich uit vrije wil volledig aan het gezin wijdden, verdienden alle respect. Dit pleidooi - dat nog maar weinig van zijn "modern" tintje verloren heeft - werd vooral kracht bijgezet door Elisa Van Langendonck ${ }^{(38)}$. Zonder een verbod op vrouwenarbeid te vragen, stelde ze voor om gehuwde vrouwen een vergoeding - een "huisvrouwenloon" - uit te keren zodat ze konden thuisblijven. Veel gehuwde vrouwen waren gedwongen te gaan werken om het ontoereikend loon van hun echtgenoot aan te vullen. Dit terwijl ze liever thuis zouden blijven om voor hun kinderen te zorgen in plaats van hen uit te besteden of langs de straat te laten zwerven. Wanneer ze door de overheid vergoed werden voor het werk dat ze deden als huisvrouw zou de noodzaak loonarbeid te verrichten verdwijnen. Het huishouden en de verzorging en opvoeding van de kinderen waren immers taken van maatschappelijk nut en moesten als dusdanig door de Staat gewaardeerd en vergoed worden.

De socialistische feministen meenden dat ze hun eisen het beste kracht konden bijzetten door zich te verenigen, bij voorkeur onder de vlag van het socialisme. Van onder de vleugels van de socialistische beweging konden de vrouwen ijveren voor een arbeidsduurverlaging, voor "gelijk loon voor gelijk werk" en voor respect voor het huishoudelijk werk. Zo moesten de vrouwen mee met de mannen vechten voor de achturendag. De realisatie van deze socialistische eis was immers ook van belang voor de vrouwen.

De strijd voor de feministische eisen kon ook gebeuren vanuit de vakbeweging (39). De arbeidsters hadden er alle voordeel bij zich aan te sluiten 
bij de reeds bestaande vakbonden of eigen vakverenigingen op te richten. Op die manier konden ze hun eisen kracht bijzetten. "Samen sterk". De slechte arbeidsvoorwaarden waren volgens de socialistische feministen immers te wijten aan het feit dat de arbeidsters niet georganiseerd waren. De mannen hadden gesteund door de vakbonden strijd geleverd voor hogere lonen en met succes. Het werd tijd dat de vrouwen dit voorbeeld volgden. De mannen moesten de vrouwen helpenzich te organiseren. Ze moesten hen overigens beschouwen als medestrijdsters, niet als concurrentes. Wanneer ze zich samen organiseerden, konden ze samen strijd voeren.

Volgens sommige feministen volstond het niet dat de vrouwen zich aansloten bij de socialistische strijd. Zij meenden dat de enige weg waarlangs de arbeidsters konden ontsnappen aan de uitbuiting door het kapitalisme het veroveren van het stemrecht en de deelname aan hetopenbaar leven was (40).

Zoais blijkt schaarden niet alle socialisten zich achter het officiële partijstandpunt. Vertrekkende vanuit de realiteit - veel vrouwen moesten nu eenmaal gaan werken - eisten ze het recht op arbeid voor vrouwen op. Ze zagen wel in dat er misbruiken waren in de industrie, maar meenden dat de mannen net zo goed uitgebuit werden. Het had dan ook geen enkele zin om alleen de vrouwenarbeid te beschermen. Dat de vrouwen de mannen beconcurreerden met lagere lonen en het huishouden leed onder hun arbeid, gaven ze eveneens toe. Als oplossing hiervoor werd "gelijk loon voor gelijk werk" en het verlichten van de huishoudelijke taken voorgesteld.

Deze visie werd gedeeld door een minderheid binnen de BWP waartoe zowel feministen - die het recht op loonarbeid beschouwden als een middel tot vrouwenemancipatie - als realisten - die aan den lijve ondervonden dat het vrouwenloon nodig was om te overleven - behoorden.
4. Waar de socialisten hun mosterd haalden: de socialistische voorvaders en de Eerste Internationale.

[...] à nos yeux la femmen'est pas producteur dans l'acception économique du mot, c'est-à-dire un créateur de valeurs destinées à la circulation, d'objets destinés à sortir du groupe familial pour servirà la consommation publique, de produits échangeables dans la société contre d'autres produits ${ }^{(41)}$.

In de BWP leefden in de periode 1885-1914 twee visies op vrouwenarbeid naast mekaar : het officiële partijstandpunt dat de vrouwen aan de haard hoorden en het minderheidsstandpunt dat ook vrouwen recht hadden op (fabrieks) arbeid. Deze visies leefden opmerkelijk vreedzaam naast mekaar. Het feministische standpunt werd gedoogd binnen de partij. De feministen lieten niet alleen van zich horen binnen de vrouwenbeweging, ze kwamen ook aan bod op de partijcongressen en vulden nu en dan de kolommen van Vooruit en Le Peuple.

Op geen enkel moment kwam het tot een confrontatie tussen de twee groepen. Het officiële partijstandpunt week niet voor dat van de feministen, daarvoor was het te sterk. In de dertig jaar voor de Eerste Wereldoorlog bleef het onveranderd. De feministen slaagden er niet in het te beïnvloeden. Daarvoor waren ze niet machtig genoeg. Ze vormden een minderheid in de partij, maar wel een gehoorde minderheid. Misschien had hun stem luider geklonken als alle vrouwen zich achter het socialistisch feminisme hadden geschaard. De vrouwen rond La Femme Socialiste en vele anderen volgden immers trouw de partijlijn. De invloed van de feministen zou wellicht echter nauwelijks groter geweest zijn.

Eliane Gubin meent dat het ideaal van de vrouw aan de haard een burgerlijke creatie is die in de tweede helft van de negentiende eeuw aan de arbeiders werd doorgegeven en die hoofdzakelijk 
tot doel had de maatschappelijke orde - brave volgzame arbeiders tegenover een burgerlijke elite - te bestendigen ${ }^{(42)}$. Dit zou betekenen dat er een breuk was in het socialistische denken en dat socialisten oorspronkelijk positief stonden tegenover de vrouwenarbeid. Verwijzingen in de bronnen, waarvan de mooiste wel Liebknechts uitval naar Vandervelde op het congres van de Tweede Internationale van 1891 is, doen evenwel de vraag rijzen of dit wel klopt ${ }^{(43)}$.

Is er inderdaad sprake van een breuk in - een deel van - het socialistische denken : van een overwegend open of toch minstens neutrale houding tegenover de vrouwenarbeid naar het ideaal van de vrouw aan de haard, terwijl slechts een minderheid vasthield aan het oorspronkelijke standpunt? Of vinden we sporen van continuïteit : verdedigers van de vrouwenarbeid als voorouders van de feministen en tegenstanders als voorlopers van de officiële partijlijn?

Het antwoord - of althans een deel ervan - wordt gezocht in de congresverslagen van de Eerste Internationale en in teksten van en over de socialistische stamvaders ${ }^{(44)}$. Een ander deel moet gezocht worden in het werk van de katholieke, liberale en andere denkers wiens ideeën invloed hadden op het socialistische denken. Dit zou ons evenwel te ver leiden, vandaar dat we ons beperken tot de "socialistische" component van het antwoord.

Uit de teksten van de vaders van het marxisme, Marx en Engels, blijkt dat ze de vrouwenarbeid niet radicaal veroordeelden. $Z e$ verbonden de emancipatiestrijd van de vrouwen met die van de arbeiders. Volgens hun theorie vormde het vrouwenvraagstuk een deel van de sociale kwestie $^{(45)}$. Samen met de sociale kwestie zou ook de vrouwenkwestie opgelost worden.

Ze zagen geen heil in de afschaffing van de vrouwenarbeid. De vrouwen moesten steeds de kans krijgen een eigen inkomen te verwerven. Wel moest er een einde komen aan de neveneffecten van de vrouwenarbeid in de fabrieken, zoals de hoge kindersterfte en de vernietiging van het gezinsleven. Het huishouden en de zorg voor de kinderen was immers in belangrijke mate de taak van de vrouw ${ }^{(46)}$. Hun deelname aan de industriële productie maakte het gezinsleven van de arbeiders evenwel onmogelijk. Het huis lag er onverzorgd en vuil bij. Er was bovendien niemand thuis om op de kleine kinderen te passen. De kindersterfte, vooralonder zuigelingen, was hierdoor bijzonder hoog.

De vrouwenarbeid had ook gevolgen voor de gezondheid van de arbeidsters zelf. Sommige vrouwen leden aan misvormingen van het bekken of de gewrichten. Anderen hadden ademhalingsmoeilijkheden en longaandoeningen. Bovendien hadden de arbeidsters vaak moeilijke en zware bevallingen en was het aantal miskramen groot. De vrouwen werkten zolang mogelijk door voor de bevalling en gingen daarna zo vlug mogelijk weer aan de slag uit angst hun loon of werk te verliezen. Dit was nefast voor de gezondheid van vrouwen en kinderen. De arbeid van mannen, vrouwen en kinderen in dezelfde werkplaatsen en bovendien door de hitte en de vochtigheid vaak half naakt uitgevoerd leidde ook vaak tot onzedelijkheid en een hoog aantal onechte kinderen.

Zowel Marx als Engels meenden dat de vrouwen in de industrie beschermd moesten worden. In 1875 schreef Karl Marx in reactie op het programma van Gotha dan ook dat niet alleen de arbeidsdag gereglementeerd, maar tegelijkertijd ook de vrouwenarbeid beperkt moest worden ${ }^{(47)}$. In de socialistische samenleving zouden de vrouwen nog steeds mogen werken in de grootindustrie. Eens ontdaan van zijn kwalijke kanten zou hun arbeid zelfs een bron van welzijn en geluk zijn. De Staat zou de huishoudelijke taken en de opvoeding van de kinderen van de vrouwen overnemen. Samen met het beëindigen van de uitbuiting van beide seksen zou dit aan de basis liggen van de maatschappelijke gelijkheid van de geslachten.

Ons hierop baserend zouden we inderdaad kunnen besluiten dat er een breuk is in het socialisti- 
sche denken inzake vrouwenarbeid. Immers, Marx en Engels bepleitten nergens het afschaffen van de vrouwenarbeid, terwijldit op het eindevan de negentiende eeuw wel het geval was in de BWP. Enkel een minderheid van de Belgische socialisten zat nog op dezelfde golflengte als Marx en Engels. Gaan we evenwel nog een stap verder terug, naar de utopische socialisten, dan vinden we wel twee visies op vrouwenarbeid.

Charles Fourier en de Saint-Simonisten waren zowel socialistisch als feministisch ${ }^{(48)}$. Ze streefden de verbetering van de situatie van de arbeiders - ongeacht hun geslacht - en van de vrouwen - ongeacht hun klasse - na. De vrouwen en arbeiders werden het meest vernederd in de maatschappij, vandaar dat de verbetering van hun lot het eerste was waarvoor geijverd moest worden. Zowel Fourier als de volgelingen van de Saint-Simon legden de nadruk op de economische zelfstandigheid. Door het verwerven van hun eigen inkomsten konden de vrouwen onafhankelijk worden van de mannen. Het recht op arbeid werd gezien als de sleutel tot de emancipatie van de vrouwen.

In Fouriers ideale samenleving had iedereen recht op arbeid. Het huishoudelijke werk werd net als alle andere arbeid verdeeld over alle mensen. Het werd bovendien vereenvoudigd door elke huizenblok te voorzien van gemeenschappelijke voorzieningen als een keuken, een eetzaal en een wasruimte ${ }^{(49)}$. Op deze manier werd het huishouden niet alleen veel eenvoudiger, er werd ook veel tijd uitgespaard. Fourier veronderstelde dat veel vrouwen voor het huishouden zouden kiezen, hoewel ze van geen enkele arbeid uitgesloten werden. Het geslacht speelde geen rol meer bij de verdeling van de arbeid, wel aanleg en kracht. De beide geslachten kregen met andere woorden gelijke kansen op de arbeidsmarkt. De inkomsten werden eerlijk verdeeld over de arbeiders, afhankelijk van de arbeid, het kapitaal en het talent dat ze inbrachten. Devrouwen zouden dus niet noodzakelijk minder verdienen enkel en alleen omdat ze vrouw waren.
Fourier keurde het bestaande gezinstype af, omdat het de vrouwen dwong huishoudster te zijn, ook als ze dit niet wilden. Hij betwistte eveneens dat de kinderverzorging en de zorg voor het huishouden exclusief taken van de vrouwen waren.

Henri de Saint-Simon zelf had weinig aandacht voor de vrouwenkwestie. Zijn volgelingen, de Saint-Simonisten hebben zijn theorie op dit punt uitgediept. Ze streefden naar de gelijke behandeling van mannen en vrouwen in de maatschappij, ook op het vlak van de arbeid. Enfantin, de leider van de Saint-Simonisten, verzette zich tegen het idee dat de vrouwen van nature uit huiselijk waren, dat dit aangeboren was ${ }^{(50)}$.

Nadat de Saint-Simonisten in twee groepen uiteenvielen, trok Enfantin zich met een aantal volgelingen terug om te proberen te ontdekken wat het precies inhield om een vrouw te zijn ${ }^{(51)}$. Eén van hun middelen om inzicht te krijgen in de "vrouw" bestond erin zelf het huishouden te doen, wat bij de toenmalige Franse bevolking overkwam als lachwekkend en tegennatuurlijk.

Proudhon, eveneens een vroege socialist, was de tegenpool van Fourier en de Saint-Simonisten. In tegenstelling tot deze laatsten was hij een felle antifeminist. Volgens hem waren de vrouwen minder waard dan de mannen ${ }^{(52)}$. Op zich hadden ze geen reden van bestaan, behalve dan als "reproductiekracht" en moeder. Het moederschap en alles wat daarmee samenging, van de maandelijkse menstruatie over de zwangerschap tot de borstvoeding, was zeer zwaar voor de vrouwen. Wanneer ze kinderen hadden, konden de vrouwen niets anders meer doen dan voor hen zorgen. Ze konden met andere woorden geen loonarbeid verrichten en waren dus volledig afhankelijk van de man.

De minderwaardigheid van de vrouwen kon op geen enkele manier gecompenseerd worden. Ze werd in tegendeel voortdurend erger. De ontwikkeling van de industrie had een stijgende nood aan arbeiders enerzijds en aan kennis en fysieke kracht anderzijds tot gevolg. Deze laatste eigen- 


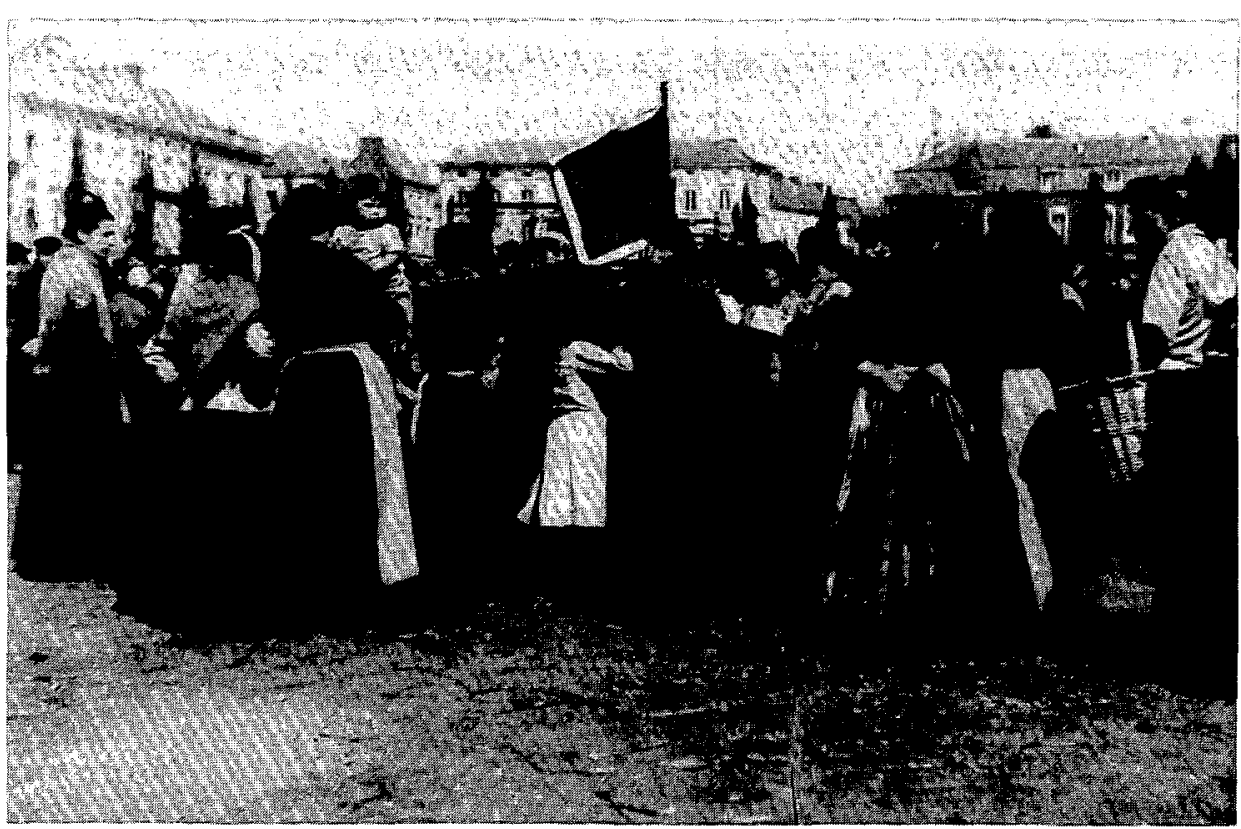

Vrouwen betogen voor Algemeen Stemrecht, Gent, 1893

schappen ontbraken bij de vrouwen echter zo goed als volledig. Ze waren de industrie bijgevolg van weinig of geen nut. De stijgende nood aan arbeidskrachten betekende bovendien dat er meer kinderen geboren moesten worden. De taak van de vrouwen, namelijk het krijgen van kinderen, verzwaarde hierdoor.

Ook intellectueel moesten de vrouwen het onderspit delven. Dit had tot gevolg dat de kwaliteit van de door de vrouwen geleverde arbeid ver onder die van de mannen lag. Bovendien konden de vrouwen minder lang en minder intensief werken. Ook dit was een reden waarom de vrouwen ongeschikt waren om deel te nemen aan de industriële productie.

Het enig punt waarop de vrouwen superieur waren, was de schoonheid. Op dit vlak overtroffen ze de mannen, maar dit gaf hen geen recht op een plaats op de arbeidsmarkt. Integendeel, de taken van de vrouwen beperkten $z$ ich tot het huishouden, de opvoeding van de jonge kinderen, het onderrichten van jonge meisjes en de openbare liefdadigheid. Geen enkele industrie was geschikt voor hen. Het huishouden was hun enige roeping. De vrouwen konden zich op tal van vlakken nuttig maken en moesten dit ook doen, maar in de industrie zouden ze nooit meer dan een aantal minder belangrijke taken kunnen vervullen. Het huishouden was de volledige uitdrukking van het vrouw-zijn, haar koninkrijk. Terwijl de mannen instonden voor de productie, waren de vrouwen verantwoordelijk voor de consumptie binnen het gezin.

Waren de vaders van het socialisme - Marxen Engels - eensgezind over de deelname van de vrouwen aan de fabrieksarbeid mits het inperken van de misbruiken, dan vinden we bij de grootvaders ervan - Fourier, de Saint-Simon en Proudhon - twee strekkingen terug. De eersten verdedigden het recht op arbeid voor vrouwen, terwijl Proudhon beschouwd kan worden als de vader van het ideaal van de vrouw aan de haard. Ook onder de Belgen van de Eerste Internationale vinden we deze twee visies terug.

Op het congres van 1867 verwoordde César De Paepe het Belgischestandpunt inzake de fabrieks- 
arbeid van vrouwen ${ }^{(53)}$. Hierover bestond geen eensgezindheid. De Paepe las dan ook twee verslagen voor : dat van de meerderheid van de Belgische afdeling en dat van de minderheid. In het eerste verslag - waar De Paepe zich achter schaarde - stond dat er op dat moment geen enkel middel bestond om de situatie van de vrouwen in de industrie te verbeteren, op de beperking van de arbeidsduur na. De vrouwen hoorden bovendien niet thuis in de fabrieken en ateliers, maar wel in het gezin. Men moest dan ook krachtig protesteren tegen de industriële arbeid van de vrouwen en wel om verschillende redenen.

In de eerste plaats deed de concurrentie van de vrouwen de mannenlonen dalen. De arbeidsters konden tegen lagere lonen werken, omdat hun behoeften geringer waren dan die van de mannen. Hun arbeid was lichamelijk minder zwaar, vandaar dat de industriëlen er niet zoveel voor wilden betalen. De concurrentie die op deze manier ontstond was er de oorzaak van dat de mannen uiteindelijk ook tegen lagere lonen moesten werken. Dearbeidsters uit de gemengde beroepen halen en alleen nog de specifiek vrouwelijke beroepen voor hen overlaten, was geen oplossing. In de vrouwenberoepen zou de concurrentie dan zodanig toenemen dat de lonen onder een leefbaar minimum zouden dalen.

De deelname van de vrouwen aan de industriële productie leidde bovendien tot de verwaarlozing van het gezin. De arbeidsters hadden weinig tijd om zich met het huishouden bezig te houden. De vrouwenarbeid hield ook mee de onwetendheid in stand. De vrouwen hadden weinig onderwijs genoten en het beetje kennis dat ze hadden, konden ze wegens tijdgebrek niet aan hun kinderen doorgeven. De vrouwenarbeid was er tevens de oorzaak van dat de menselijke soort erop achteruit ging. De arbeidsters hadden geen tijd om hun kinderen de borst te geven. Ze lieten hun kinderen achter bij voedsters waar het sterftecijfer over het algemeen hoog lag. Daarnaast overtrof hun arbeid vaak hun krachten, waardoor ze zelf verzwakt raakten. Een gezonde moeder was nochtans een eerste voorwaarde om gezonde kinderen voort te brengen. In de socialistische maatschappij zouden de vrouwen geen fabrieksarbeid meer verrichten, maar zouden ze de rol waartoe ze voorbestemd waren - het moederschap - kunnen vervullen. Weduwen zouden een uitkering krijgen, zodat ze zich aan de opvoeding van hun kinderen konden blijven wijden. Jonge weduwen en ongehuwde vrouwen moesten op zoek gaan naar een echtgenoot om een gezin mee te stichten. Vrijwillig ongehuwde vrouwen waren "une monstruosité" waarvan de meerderheid van de Belgische afdeling van de internationale niets begreep. Het vrijwillige celibaat was echter geen excuus om in de industrie te gaan werken. Er waren immers nog tal van zaken waar deze vrouwen zich bij voorkeur aan konden wijden : ziekenzorg, zorg voor de wezen en dergelijke.

Een minderheid binnen de Belgische afdeling van de Internationale hield vast aan het recht op atbeid dat niemand - ook de vrouwen niet - ontzegd kon worden. Arbeid was een bron van onafhankelijkheid en waardigheid, ook voor vrouwen. De oorzaak van de dalende mannenlonen moest gezocht worden in de manier waarop de arbeid georganiseerd was. In de toekomstige socialistische maatschappij kon dit probleem opgevangen worden door van bij het begin rekening te houden met de vrouwelijke arbeidskrachten.

De onzedelijkheid op de werkplaatsen werd niet veroorzaakt door de arbeid zelf, maar door externe factoren, namelijk door opdringerige opzichters en patroons. De lage lonen dwongen de vrouwen hierop in te gaan. Het argument dat de vrouwen lichamelijk minder sterk waren dan de mannen was op zich niet voldoende om de vrouwenarbeid af te schaffen. Vrouwen waren immers handig en behendig waardoor een heleboel beroepen uitermate geschikt waren voor hen. Bovendien zorgde de toenemende mechanisatie ervoor dat er steeds minder fysieke kracht vereist was om in de industrie te werken.

Het moederschap hoefde evenmin een belemmering te vormen voor de deelname van de 


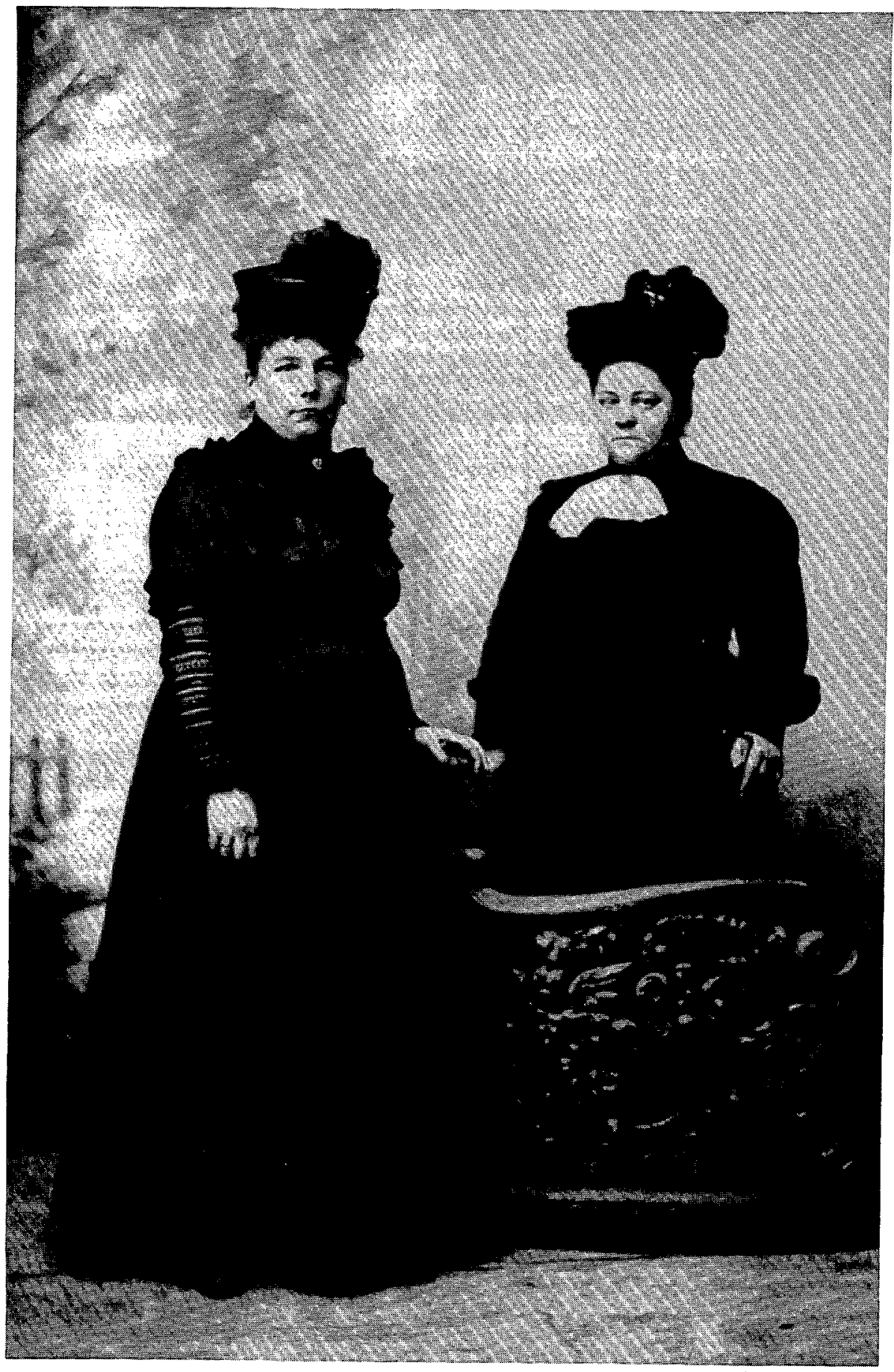

Liza De Deyster, voorzitster van de socialistische vrouwenvereniging "Noordstar" van Oostende, augustus 1908 (foto Henriëtte De Backer) 
vrouwen aan de industriële productie. De gehuwde vrouwen konden het huishouden zoveel mogelijk uit handen geven aan gespecialiseerde bedrijven, zoals wasserijen, grootkeukens en kindertuinen. De vrouwen konden alleen niet werken op het einde van hun zwangerschap en zolang de kinderen heel klein waren. Op die momenten moesten ze kunnen terugvallen op het loon van hun man of op speciaal daarvoor opgerichte hulpkassen. Voor het overige kon men de vrouwen niet dwingen thuis te blijven. Het was dan ook de taak van de Internationale de vrouwen ertoe aan te zetten zich te verenigen zodat ze konden vechten voor de emancipatie van hun arbeid en zo hun onafhankelijkheid konden garanderen.

Onder de Belgische socialisten in de Eerste Internationale kunnen bijgevolg twee stromingen onderscheiden worden die respectievelijk beïnvloed werden door Fourier en de Saint-Simonisten en Proudhon. Er bestond bijgevolg zowel een feministische als een anti-feministische traditie binnen het socialistische denken. Eén lijn liep van Fourier en de Saint-Simonisten over Marx en Engels naar de feministen uit de jaren 1885-1914 en één van Proudhon over de meerderheid van de Belgische socialisten in de Eerste Internationale naar het officiële BWP-standpunt voor de Eerste Wereldoorlog.

Gubins stelling komt hiermee op de helling te staan. Het ideaal van de vrouw aan de haard was niet burgerlijk in de zin dat het door de burgerij gecreëerd werd en later doorsijpelde bij de arbeiders. Dit ideaal was even goed origineel socialistisch vermits er sporen van te vinden zijn bij een aantal utopische socialisten. Binnen de socialistische beweging leefden twee visies op vrouwenarbeid naast mekaar, beide met wortels binnen de beweging zelf.

\section{Besluit.}

Uit ons onderzoek naar de visies op de fabrieksarbeid van de vrouwen die vóór de Eerste Wereldoorlog leefden bij de Belgische socialisten blijkt dat twee strekkingen vreedzaam naast mekaar bestonden. De meerderheid van de socialisten keurde de fabrieksarbeid af, omdat de arbeidsters hun gezin verwaarloosden en bovendien de mannen uit de arbeidsmarkt dreigden te concurreren. $\mathrm{Zij}$ droomden van een - socialistische - maatschappij waarin de vrouwen geen loonarbeid buitenshuis meer zouden verrichten. Tot de komst van deze maatschappij stelden ze zich tevreden met de wettelijke beperking van de vrouwenarbeid en de opvoeding van de vrouwen tot huismoeders. De Waalse socialisten ijverden daarenboven voor "gelijk loon voor gelijk werk", terwijl de Vlamingen meer heil zagen in een gezinsloon voor de man.

De realisten onder de socialisten - in hoofdzaak feministen - waren niet voor deze oplossingen gewonnen. Hoewel ze de wantoestanden in de industrie niet ontkenden, meenden ze dat deze niet konden opgelost worden door de vrouwen te weren uit de fabrieken. Teveel vrouwen en gezinnen hadden het inkomen van de vrouw nodig om te kunnen overleven. Maatregelen die de vrouwen marginaliseerden op de arbeidsmarkt brachten huns inziens geen zoden aan de dijk. Integendeel, ze ondermijnden de mogelijkheden van de vrouwen om een eigen inkomen te verdienen. Een minderheid van de socialisten verdedigde daarom het recht op arbeid voor de vrouwen. Er dienden inderdaad maatregelen genomen te worden om de misbruiken in de industrie te beperken - zoals de wettelijke regeling van de arbeid van mannen en vrouwen, het verlichten van de huishoudelijke taken en het gelijk vergoeden van mannelijke en vrouwelijke arbeidskrachten. Op die manier zouden vrouwen en mannen "collega's" worden in de echte zin van het woord en konden beide geslachten door hun 
arbeid een leefbaar inkomen verdienen.

In tegenstelling tot wat wel eens beweerd wordt, vonden beide strekkingen hun wortels bij socialistische denkers. De tegenstanders van de fabrieksarbeid voor vrouwen sloten nauw aan bij de ideeën van Proudhon. Zijn opvattingen over vrouwen en vrouwenarbeid leefden door bij de meerderheid van de Belgische socialisten in de Eerste Internationale en beïnvloedden het officiële partijstandpunt van de BWP vóór de Eerste Wereldoorlog. Fourier en de Saint-Simonisten van hun kant, evenals de gematigde standpunten van Marx en Engels kunnen herkend worden in de visie van de minderheid van de Belgen in de Eerste Internationale en van de socialistische feministen in de periode 1885-1914.

* Dit artikel is de bewerking van een deel vandelicentiaatsverhandeling O...dievrouwen!... (N.BRACKE, 1995).

\section{EINDNOTEN}

(1) L. Bertrand, De Belgische Werklieden-partij en haar programma, Gent, 1886, 37. Onze onderstreping.

(2) Programma der Belgische Werkliedenpartij aangenomen door het buitengewoon congres van den 15 juli 1894 te Brussel, Cent, 1894, 1.

(3) S. Poldervaart, Tegen conventioneel fatsoen en zekerheid. Het uitdagend feminisme van de utopisch socialisten en "Vrouwelijke kwaliteiten voor alle mensen ? Discussies over vrouwelijkheid aan de hand van het Franse utopisch-socialistische feminisme, 1830-1850".

(4) "Onze huismoeder", Vooruit, 12.04.1897/2,B

(5) Compte rendu du X́lle congrès annuel tenu à la Maison du Peuple, Charleroi-Nord, les 5 et 6 avril 1896, Bruxelles, 1896, 101. Onze onderstreping.

(6) "Kindersterfte in de nijverheidssteden", Vooruit, 24.12.1889/1,ABC; P. De Bruyne, "Het vrouwenstemrecht", Vooruit, 30.07.1901/1,AB e.a.

(7) "Kindersterfte in de nijverheidssteden", Vooruit, 24.12.1889/1,ABC; F. Hardyns, "La mortalité des enfants", Le Peuple, 22.10.1892/1,A e.a.

(8) L. Bertrand, "Les misères du siècle", Le Peuple, 23.01.1888/1,A; "De vrouw in den strijd tegen den drank", Vooruit, 22.01.1889/1,ABCD e.a.

(9) "De socialistische vrouwenvereniging te Gent", Vooruit, 21.01.1888/1,A; "In de socialistische school. De loonkwestie", Vooruit, 24.01.1910/1,B e.a.

(10) L. Bertrand, "La prostitution", Le Peuple, $16.07 .1886 / 1$, A e.a.
(11) J. Volders, "Les ouvrières et leurs droits", Le Peuple, 01.08.1888/1,B; "Aan onze vrouwen", Vooruit, 28.04.1892/1,D e.a.

(12) L. Bertrand, "Le travail des femmes", Le Peuple, 17.03.1890/1, A; "Het christendom en de vrouwen", Vooruit, 23.09.1892/1,A e.a.

(13) Le Peuple, 28.04.1886/1, C e.a.

(14) "Redevoering van gezel Anseele", Vooruit, $07.08 .1889 / 1, A$.

(15) "Het vrouwenwerk", Vooruit, 10.05.1898/1, B e.a.

(16) ). V[olders], "La section d'art à la Maison du Peuple. La condition sociale de la femme", Le Peuple, $17.12 .1892 / 1, \mathrm{D}$ e.a.

(17) "De toekomst der vrouw", Vooruit, 19.12.1892/1,D; G. Defnet, "Les écoles ménagères", Le Peuple, $10.01 .1893 / 1$, A e.a.

(18) Nellie, "Voor de moeders", Vooruit, 25.01.1886 t/m $15.04 .1886 \mathrm{e} . \mathrm{a}$.

(19) "Hebben de werklieden een familieleven ?", Vooruit, $01.08 .1885 / 1$ A e.a.

(20) L. Bertrand, "Les femmes hors de la mine", Le Peuple, 26.07.1889/1,B e.a.

(21) [Emilie Claeys], "Wettelijke bescherming der arbeidsters", De Stem der Vrouw, I, 1894, 13, p. 2.

(22) Vooral in La Femme Socialiste werd het officièle partijstandpunt vertolkt.

(23) M. Tillmans, "Le congrès extraordinaire du Parti Ouvrier. Rapport sur le suffrage des femmes", Le Peuple, 19.06.1907/1.A.

(24) R. D., "De toekomst der vrouw", Vooruit, 21.12.1892/1, C e.a.

(25) "Le travail industriel des fernmes. Rapport de la citoyenne Huyghens", La Femme Socialiste, I, 1903, 3, p. 2.

(26) "Bescherming van de vrouwenarbeid", De Vrouw, IV, 1897,17 , p. 132 e.a.

(27) I. Gatti De Gamond, "L'ouvrière - Conditions du travail des femmes", Cahiers Féministes, X, 1905, 78, p. 5 e.a.

(28) [E. Claeys], "Wettelijke bescherming der vrouwen", De Vrouw, II, 1894, 1, p. 2 e.a.

(29) J. V. D. Veer, "Ingezonden. Vrouwenarbeid", De Vrouw, I, 1894, 10, p. 7 e.a.

(30) K. Pearson, "De vrouw en de arbeid", De Vrouw, III, 1896,17, p. 131 e.a

(31) [E. Claeys], "Wettelijke bescherming der vrouwen", De Vrouw, II, 1894, 1, p. 2; Rienzi, "Regeling van den vrouwen-arbeid", De Vrouw, III, 1896, 13, p. 103.

(32) "Wettelijke bescherming voor vrouwen", De Stem der Vrouw, IV, 1903, 6, p. 6 e.a.

(33) E. Claeys, "De vrijmaking der vrouw", De Vrouw, I, 1893, 3, p. 10; SOFIE, "Ter opwekking der vrouw". De Stem der Vrouw, IV, 1903, 6, p. 4 e.a.

(34) J.V.D. Veer, "Ingezonden. Vrouwenarbeid", De Vrouw, I, 1894, 10, p. 7; L. Meysmans, "Congrès féministe", Le Peuple, 27.07.1899/1,A e.a.

(35) N[ellie], "Verslagen", De Vrouw, I, 1894, 14, p. 5; "Het vrouwencongres te Charleroi", Vooruit, 26.07.1899/1,A e.a.

(36) Rienzi, "Vrouwen-beweging", Vooruit, 04.06.1895/1, A e.a.

(37) A. B [ogaerts], "Over moederschapsverzekering. Eene leemte in ons programma", Vooruit, 25.03.1909/1,A e.a.

(38) "Socialistisch congres gehouden in het "Volkshuis" te Brussel", Vooruit, 11.03.1902/2,D; E. Van Langendonck, "Vergoeding door den Staat van het werk der huisvrouwen", De Stem der Vrouw, III, 1902, 4, pp 4-5.

(39) "Het vrouwencongres te Charleroi", Vooruit, 
26.07.1899/1,A. Esther, "De vrouwen en de vakvereniging", De Stem der Vrouw, IV, 1903, pp. 1-2; "Femmes, unissons-nous!", Cahiers Féministes, IX, 1904,48 , pp. 1-2 e.a.

(40) I. Gatti De Gamond, "Polémique et féminisme", Cahiers Féministes, VIII, 1903, 38, pp. 3-4 e.a.

(41) César De Paepe op het tweede congres van de Eerste Internationale te Lausanne (1867). "Le congrès de Lausanne", 215.

(42) E. Gubin, "Le modèle de la femme au foyer en Belgique avant 1914", 97.

(43) In 1891 merkte Emile Vandervelde op dat de vrouwen aan de haard hoorden, waarna hij de meerderheid van de aanwezigen op het congres over zich heen kreeg, Liebknecht op kop. "Fort bien ! Courtisane ou esclave domestique, voilà comment un socialiste entend le rôle de la femme !", beet hij Vandervelde toe, hiermee verwijzend naar de woorden "Courtisane ou ménagère" waarmee Proudhon de rol van de vrouwen in de maatschappij samenvatte (CONGRES International Ouvrier Socialiste tenu à Bruxelles du 16 au 23 août 1891. Rapport, Bruxelles, 1893, 84).

(44) Fourier, de Saint-Simon, Proudhon, Engels, Marx en het recente werk van Saskia Poldervaart over de Franse utopische socialisten (zie bibliografie).

(45) ). Outshoorn, Vrouwenemancipatie en socialisme, p. 14.

(46) S. Poldervaart, Tegen conventioneel fatsoen, p. 195.

(47) K. Marx, F. Engels und W. Lenin, Uber die Frau und die Familie, 118.

(48) S. Poldervaart, "Vrouwelijke kwaliteiten voor alle mensen ?", 132.

(49) S. Poldervaart, Tegen conventioneel fatsoen en zekerheid, 120.

(50) Ibid., 109.

(51) Ibid., 113-114

(52) P.-j. Proudhon, De la justice dans la révolution et dans l'église. Tome N, p. 134 e.v.

(53) "Le Congres de Lausanne", p. 143 e.v.

\section{BIBLIOGRAFIE.}

Bracke N., O...die vrouwen 1... Visies op vrouwenarbeid. De standpunten van de Belgische Werkliedenpartij over de deelname van de vrouwen aan het gecentraliseerde productieproces. 1880-1914, Gent (onuitgegeven licentiaatsverhandeling), 1995 (promotor dr. E. Vanhaute).

De Saint - Simon H., L'oeuvre d'Henri de Saint-Simon, Paris, 1925

Fourier C., Théorie de l'unité universelle. Quatrième volume, Paris, 1841.

Fourier $C$., Théorie des quatre mouvements et des destinées générales. Prospectus et annonce de la découverte, Paris, 1846

Gatti De Gamond Z., Fourier et son système, Paris, 1842.

Gubin E., "Le modèle de la femme au foyer en Belgique avant 1914", Gubin E. (éd.), Norme et marginalités. Comportements féminins aux $19 \mathrm{e}-20 \mathrm{e}$ siècles, Bruxelles, 1991, pp. 97-115.

Marx $K_{1}$, Engels F. und Lenin W., Uber die Frau und die Familie, Leipzig, 1976.

Proudhon P.-J., De la justice dans la révolution et dans l'église. Tome IV, Bruxelles, 1868.

Poldervaart S., Tegen conventioneel fatsoen en zekerheid Het vitdagend feminisme van de utopisch socialisten, Amsterdam, 1993.

Poldervaart S., "Vrouwelijke kwaliteiten voor alle mensen ? Discussies over vrouwelijkheid aan de hand van het Franse utopisch-socialistische feminisme, 1830-1850", Jaarboek voor vrouwengeschiedenis, XII, 1991, pp. 131152.

Proudhon P.-J., La pornocratie ou les femmes dans les temps modernes, Paris, s.d.

Vandervelde E., Souvenirs d'un militant socialiste, Paris, 1939.
Bang, bang is het hart der vroww,

Bang voor honger en ellende,

Bang voor ziekte en verdriet,

Bang voor oorlog en vergaan

Zuraar, zwaar is het hart der vrouw, Zwaar, van kommer en van zorgen, Zwadr van tranen en verlangen, Zwaar van meelij en van angst.

Groot, groot is het hart der vrouw. Groot van liefde voor haar makker. Groot van blijdschap om haar kind, Groot van hoop op haa ontvoogding.
Warm, warm is het hart der vrouw, Warm van uriendschap voor haar zusters,

Warm van één-zïn met de anderen,

Warm van strijd voor't ideaal.

Rood, rood is het hart der vrouw,

Rood als rozen in de gaarden,

Rood als t bloed van zij die vielen,

Rood als vaandels in de stoet !
Yuonne De Man

14.4.1964 